\title{
CRETACEOUS STRATIGRAPHIC AND PALEOENVIRONMENTAL DATA FROM THE SOUTH ATLANTIC (FORAMINIFERS AND NANNOPLANKTON)
}

\author{
F. MAGNIEZ-JANNIN* and C. MULLER**
}

\begin{abstract}
This study is part of the Project "Lithology and Organic Geochemistry of the Atlantic Black Shales". The biostratigraphic and paleoenvironmental results are based on new investigations of foraminifers and nannoplankton from several closely sampled Deep Sea Drilling sites in the South Atlantic (Falkland Plateau: 327, 330 and 511; Cape Basin: 361; Angola Basin: 264; Walvis Ridge: 363 and 530; Rio Grande Rise: 356,357 and 516 ). It was possible to precise previously published data about the age of the sedimentary sequences, duration of heatuses, sediment accumulation rates, and paleoceanographic changes. A chronostratigraphic correlation of the different sites is given, the paleoenvironmental observations are summarized and synthetized for the South Atlantic and compared with the main events in the North Atlantic.
\end{abstract}

RESUmo Este estudo é parte do Projeto "Lithology and Organic Geochemistry of the Atlantic Black Shales". Os resultados bioestratigráficos e paleoecológicos basearam-se em novas investigações de foraminíferos e nanoplâncton de detalhada amostragem de poços do Deep Sea Drilling Project (DSDP) perfurados no Atlântico Sul (Platô de Falkland: 327, 330 e 511; Bacia do Cabo: 361, Bacia de Angola: 364; Walvis Ridge: 363 e 530; e Elevação do Rio Grande: 356, 357 e 516 . Foi possível precisar dados anteriormente publicados sobre idades das seqüências sedimentares, duração dos hiatos, taxa de acumulação de sedimentos e mudanças paleoceanográficas. Uma correlação cronoestratigráfica entre diferentes poços e observações paleoambientais para o Atlântico Sul foram sintetizadas e sumariadas, permitindo comparações com os principais eventos do Atlântico Norte.

INTRODUCTION The following biostratigraphic investigations of several Deep Sea Drilling sites from the South Atlantic (Fig. 1) were part of the Project "Lithology and Organic Geochemistry of the Atlantic Black Shales" which started in 1981 with reexamination of the North Atlantic sites (Graciansky et al. 1982, Muller et al. 1983-1984).

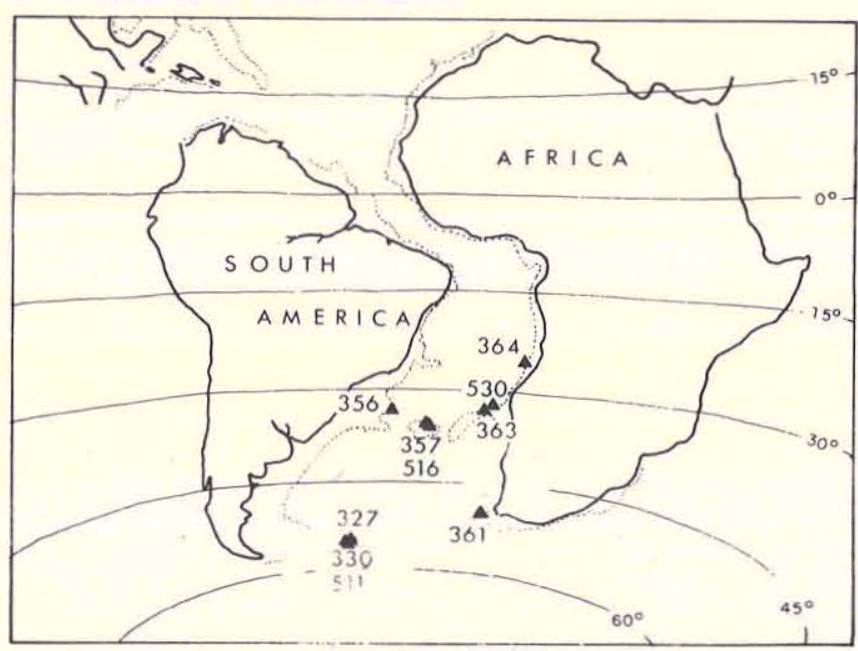

Figure 1 - Location map of the DSDP sites studied in the South Atlantic. Late Cretaceous (80 Ma) reconstruction and paleobathymetry, after Sclater et al. 1977(simplified) The dotted line is the 2,000 m contour

More homogeneous datings for comparison and correlation of geological events in both parts of the Atlantic were obtained by these reinvestigations. The given biostratigraphy is based on planktonic and benthic foraminifers and calcareous nannoplankton studied from the same samples. The following zonations and references were used for the age determinations by planktonic foraminifers: Pessagno (1967), Longoria (1974), Sigal (1977), Robaszynski, Caron et al. (1979, 1983, 1984), Weiss (1983), and Marks (1984). Publications by Cushman (1946), Hanzlikova (1972), Dailey (1973), Koch (1977), Scheibnerová $(1976,1981)$ and diverse DSDP reports were of special values for the use of benthic foraminifers. The interpretation of depositional environments, using benthic and planktonic foraminiferal assemblages, is based on studies from Sliter (1972, 1976), Scheibnerová (1976, 1978, 1981), Haig (1979), Hart \& Bailey (1979), and Guérin (1981). Datings obtained by nannoplankton are based on the zonations by Thierstein $(1973,1976)$ and Perch-Nielsen (1977).

The stratigraphic results are summarized in figure 2 . Some significant modifications have been made when compared with datings described in the Initial Reports of the Deep Sea Drilling Project.

The precise age determinations are not always possible because of different factors: 1 ) the dissolution of calcareous micro and nannofossils is one of the greatest problems being responsible for either their absence or the decrease of their assemblage diversity due to selective dissolution of the less resistant species. This can change significantly the original associations. Some variations in the degree of dissolution are related to changes of the CCD and special geochemical conditions as for example high content of organic matter or high input of detrital material; 2) some other difficulties have risen because of the absence of tethyan planktonic foraminifers which are used as zonal markers. The zonations based on benthic foraminifers are 


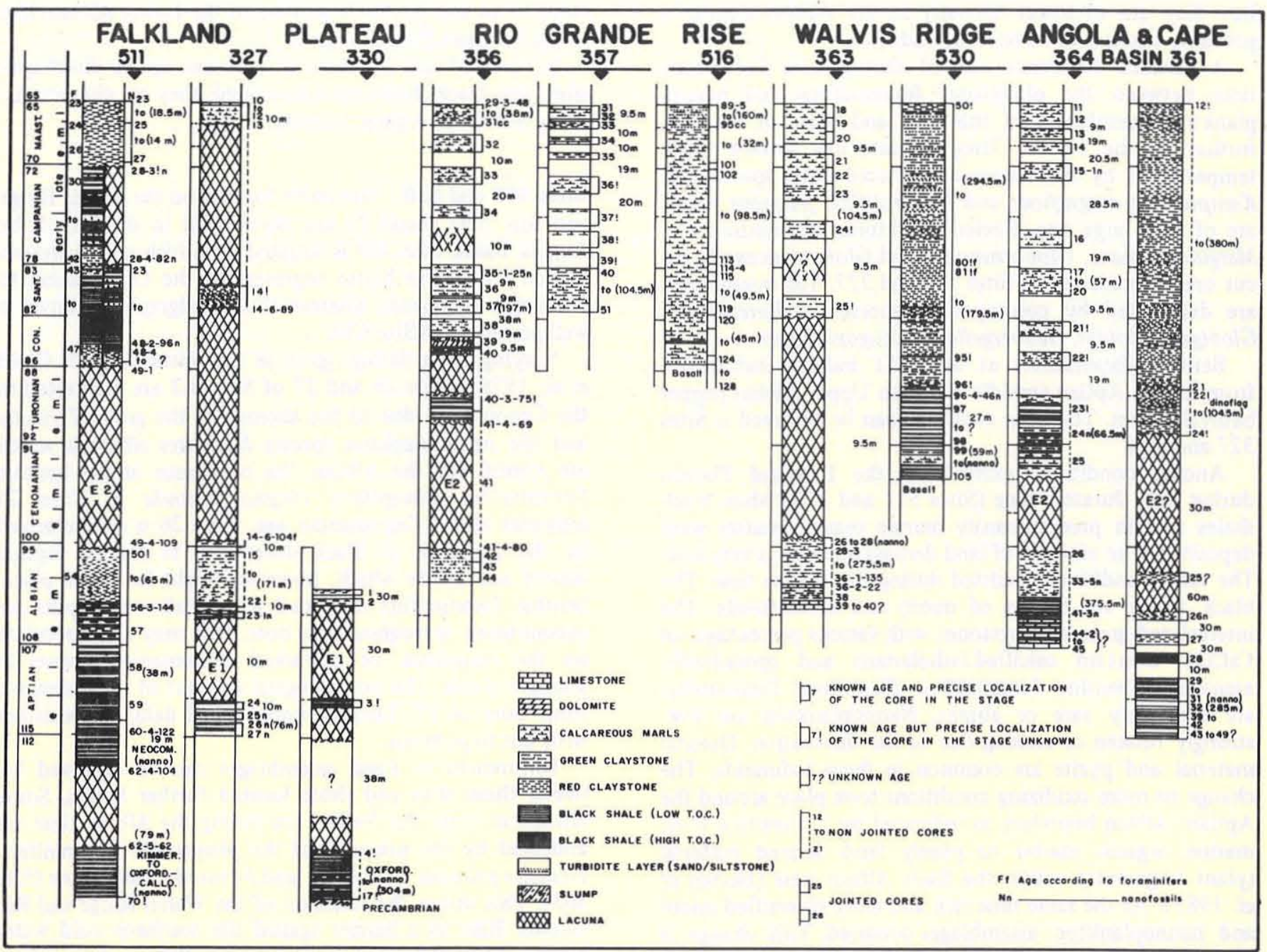

Figura 2 - Chronostratigraphy and schematic lithostratigraphy of the different sites. Time scale: upper number, after Van Hinte 1976; lower numbers, after Odin \& Kennedy 1982

not yet well established. Their distribution is strongly controlled by ecological factors; 3 ) the rework of micro and nannofossils can be another reason for difficulties in dating.

The sedimentary sequences were sampled very closely, always in regard of facies changes to reconstruct the different depositional conditions of the black shales. The kind and the origin of the organic matter in the sediments are very strong indicators to explain their formation. The observations used in this paper are based on light microscope examinations and comparisons with Rock-Eval analysis (Herbin et al. 1987).

\section{DESCRIPTION OF THE SITES Sites 511, 327 and} 330 These three sites are located very closely to each other on the Falkland Plateau (Fig. 1). The sedimentary sequences are dated from the Late Jurassic to Late Maastrichtian and interrupted by several hiatuses. The stratigraphy of Site 511 is similar to those combined from Sites 327 and 330. The difficulties to obtain precise age determinations in this area are due to the absence of tethyan forms which are used for the zonation, and also due to the strong dissolution of the Late Cretaceous foraminiferal faunas.

According to the revised data, the Cenomanian and most probably the Turonian sediments are missing at Site 511 and are correlated to the similar hiatus of Site 327. It must be noted that in certain cases the age determinations given by planktonic foraminifers are different from those obtained by nannoplankton. This is for example the case at Site 511 where, according to the foraminifers, there is a thick-sequence of Campanian sediments (Core 28-3 to Core 42), whereas according to the nannoplankton, the Campanian sediments would be missing like at Site 327 , if we use the extinction of Marthasterites furcatus as marker for the Santonian-Campanian boundary, because the latter species is found within Core 28. The dating of this sequence as Campanian rises another problem since Lithastrinus floralis, a species occuring only until the Lower Santonian, is found at the top of Core 42 .

Planktonic and benthic foraminiferal assemblages of the Lower Cretaceous are similar to those described from the Austral Province, in Australia and Indian Ocean. Endemic benthic species are among others Hergottella jonesi, Patellina africana, Gavelinella indica. Planktonic assemblages are of low diversity (no Rotaliporids, mainly Hedbergella) and some of the species show morphological differences from the typical forms. Nannoplankton assemblages of the Lower Cretaceous are similar to those known from other regions. 
But they are of lower diversity in the Aptian sediments probably because of restricted conditions.

A distinct difference existed during Late Cretaceous time between the planktonic foraminiferal and nannoplankton assemblages of this area and those of the sites further to the North. They indicate low surface water temperatures by the dominance of cold water species like Kamptnerius magnificus and Nephrolithus frequens which are of very large size. Keeled planktonic foraminifers like Marginotruncana, Globotruncana and Globotruncanella occur only sporadically at Sites 511 and 327 . The assemblages are dominated by cosmopolitan species of Heterohelix, Globigerinelloides, Hedbergella and Rugoglobigerina.

Benthic foraminifers at Site 511 indicate subsidence from Lower Aptian (middle shelf) to Upper Albian (upper bathyal) times. The same evolution can be observed at Sites 327 and 330.

Anoxic conditions existed on the Falkland Plateau during Late Jurassic time (Sites 511 and 330) when black shales rich in predominantly marine organic matter were deposited. The amount of land derived material is very low. The same conditions persisted during the Aptian time. The black shales are barren of micro and nannofossils. The intercalated greenish claystones with various percentages of $\mathrm{CaCO}_{3}$ contain calcified radiolarians and sporadically arenaceous benthic foraminifers. Planktonic foraminifers are extremely rare or absent. Nannoplankton are few, strongly broken or missing due to the dissolution. Detrital material and pyrite are common in these sediments. The change to more oxidizing conditions took place around the Aptian-Albian boundary as indicated by a transition from marine organic matter to purely land derived material (plant fragments) within the Early Albian time (Herbin et al. 1987). At the same time rich and more diversified micro and nannoplankton assemblages occurred. This change is also confirmed by benthic foraminifers which were increasing since the Late Aptian time.

A rise of the CCD is displayed at the beginning of the Coniacian-Santonian by strong dissolution, decreasing within the upper part of this stratigraphic interval and increasing again in the Upper Campanian? - Lower Maastrichtian. Zeolitic clays are the dominant facies of the Upper Cretaceous sediments of this region. Cyclic alternations of dark greenish-gray clays and lighter more calcareous clays typically occurred at Site 511 during Coniacian-Campanian times. These cycles seem to be related to different degrees of dissolution.

Site 361 It is located in the Cape Basin west off South Africa in a water depth of $-4549 \mathrm{~m}$. The age determinations for this site are very poor because of the absence of calcareous micro and nannofossils in the sediments younger than Middle Albian which were deposited below the CCD. The lower part of the sequence shows a thick turbiditic series of at least Early Aptian to Middle Albian age (according to nannoplankton). Some black shales rich in marine organic matter and nannofossils are intercalated within these turbidites and represent the autochtonous part. However, these black shales are alternating with those deposited by turbidites and containing only continental derived material and few nannoplankton diluted by the high amount of detritus. This alternation can be explained by the proximity of the continent and a periodically input of detrital material from the margin either due to some climatic changes or a tectonic instability. Anoxic conditions came to an end by the beginning of the Lower Albian, like in the Falkland Plateau region.

In cores 24 and 23, dated of Turonian age by dinoflagellates, few black shales are intercalated: they are characterized by terrestrial organic matter.

Sites $\mathbf{3 6 3}$ and 530 Site 363 is located on the Walvis Ridge and Site 530 about $20 \mathrm{~km}$ north of it in the SE of the Angola Basin. Site 363 is situated on a high and is characterized by a large hiatus representing the Cenomanian to Coniacian sediments whereas this stratigraphic interval is well presented at Site 530 .

Varying from datings given in the Initial Reports (Bolli et al. 1978), cores 26 and 27 of Site 303 are attributed to the Cenomanian due to the absence of the group Ticinella and the nannoplankton species Hayesites albiensis which are typical for the Albian; the occurence of the benthic foraminifer Osangularia insigna secunda in Core 26 indicates also a Cenomanian age. Core 26 is characterized by the presence of black shales rich in marine organic matter and pyrite which, however, might be not in place; benthic foraminifers displaced from shallower depths are encountered throughout this core. One may also speculate on the ocurrence of reworked Cenomanian faunas in younger strata. The mineralogical content of the sediments from Core 26 (T. Jacquin, unpublished data) is consistent with this hypothesis.

Differences in fossil assemblages can be observed between these sites and those located further South. Some influences from the Tethys sea during the Albian time are indicated by the presence of the planktonic foraminifers Ticinella primula, T. roberti, and Favusella washitensis (Site 363). This shows the function of the Walvis Ridge and Rio Grande Rise as a barrier against the southern cold water masses. This difference is even more distinct during Late Cretaceous time. The nannoplankton assemblages are characterized by the scarcity of cold water species and the occurrence of subtropical-tropical forms. The planktonic foraminiferal assemblages contain also some tethyan species (Globotruncanids) since Turonian time. The greatest diversity is observed in the middle Mastrichtian with various Heterohelicids and restricted tethyan species present.

At Site 363, the benthic foraminifers indicate a subsidence from shelf to upper bathyal environment during Albian time. Subsidence of the Falkland Plateau took place at the same time.

At Site 363, the sedimentary sequence consists predominantly of marly chalk deposited above the CCD. However, the dissolution increased at least since Santonian (Core 25). Nannoplankton are rare within these sediments because of the recrystallization; benthic foraminifers only occur.

There are no black shales present at the bottom of Site 363 since oldest sediment dated at this site are of Middle Albian age, a time during which well oxidizing conditions existed.

At Site 530, a sequence ranging from Cenomanian to Late Maastrichtian times overlies the basaltic basement. It is characterized by high input of detrital material most probably coming from two different domains (Walvis Ridge and African margin). The sequence seems to be rather complete. Varying from the Initial Reports (Hay et al. 1984), the oldest sediments are dated of Cenomanian age because of the presence of Gartnerago cf. obliquum which is unknown 
from the Albian, and of the occurrence of some Plectina (foraminifer).

An overlap in the occurence of Broinsonia parca and Marthasterites furcatus in Core 78 makes it difficult to determine the Santonian-Campanian boundary. According to the foraminifers, Core 78 belongs to the Campanian. That would mean that Marthasterites furcatus has a longer range than given by Thierstein (1976) and other authors. The same phenomenon was also observed at Site 511 .

Anoxic conditions persisted at Site 530 from Cenomanian to Early Santonian. The black shales are very rich in marine organic matter particularly in the Cenomanian and

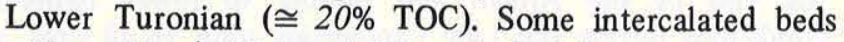
with pyrite, detrital material, and plant fragments in some of the black shales might indicate the presence of displaced material from the shelf and slope.

The series consists predominantly of red and green claystones with intercalated black shales. The green claystones are characterized by a higher content of terrigenous material and pyrite. Nannoplankton are rare but more often they are missing. They are common but strongly broken in the red claystones which contain hematite deposited under oxidizing conditions. Most ptobably, they represent the autochthonous part of the sequence.

Site 364 It is located on the margin of Angola. According to the revised data, cores 25 and 24 are respectively assigned to the Late Cenomanian and Early Turonian times.

Two periods of anoxic conditions known from the entire South Atlantic are present at this site. The first one ranging from Early Albian to the lower part of the Middle Albian is separated from the second one of latest Cenomanian to Early-Middle Turonian age by a period of well oxidizing conditions. In both cases, the black shales are very rich in marine organic matter. However, most of the Cenomanian sediments are eroded. As at Site 530, recurrent anoxic conditions existed there up to Early Santonian.

The upper part of the Middle Albian and the Upper Albian sediments are characterized by an alternation of claystones and marls as also known from other areas of the Atlantic and which is typical for this stratigraphic interval. This cyclic sedimentation might be due to climatic fluctuations. The cores 25 and 24 are rich in smectite, that might indicate volcanic activities at this time as described from the North Atlantic and North Europe (Hart \& Bigg 1981, Herbin et al. 1985).

As at Site 363, foraminiferal assemblages from Site 364 show a transitional character to a definite tethyan character throughout Cretaceous time.

Site 356 Only at Site 356 located on the São Paulo Plateau, the recovered stratigraphic interval ranging from Late Albian to Late Maastrichtian is long enough to allow some comparison with the sites of the eastern South Atlantic. This sequence is interrupted by two hiatuses, one representing the entire Cenomanian and the second one the upper part of the Turonian and the lower part of the Coniacian. The Upper Albian chalks and limestones, deposied in an upper to middle bathyal environment, are poor in nannoplankton due to the diagenesis. The occurrence of displaced material by turbidites from a shallower environment is indicated by a mixing of benthic foraminifers, the presence of Inoceramus fragments and the graded bedding.

The Lower-Middle Turonian is characterized by black shales rich in marine organic matter and pyrite. Plant fragments are rare; they are more frequent in layers with higher amount of detrital material. The nannofossils are dissolved in the black shales. As in the eastern South Atlantic, a rise of the CCD during the Early ConiacianSantonian is displayed at Site 356 by a strong dissolution at that time.

Sites 357 and $\mathbf{5 1 6}$ They are located very closely to each other on the Rio Grande Rise. As in the northeastern part of the South Atlantic, typical and even richer tethyan foraminiferal assemblages (less dissolution) are present in the Upper Cretaceous at Sites 356, 357 and 516. Although Late Albian planktonic faunas at Site 356 are of low diversity and dominated by large numbers of Hedbergella, an influence from the Tethys is indicated as soon as that time by the presence of (rare) Ticinella primula, $T$. roberti, T. breggiensis and Planomalina buxtorfi (Premoli-Silva, in Supko, Perch-Nielsen et al. 1977). By Middle Turonian time, free communication between the North and South Atlantic is evidenced by the presence of numerous Globotruncanids. Restricted tethyan species, such as Globotruncanita calcarata, Gansserina gansseri, Globotruncana aegyptiaca are found in the Late Campanian-Maastrichtian sediments, in association with numerous Heterohelicids including species of Gublerina, Pseudotextularia, Pseudoguembelina, Racemiguembelina...

CONCLUSIONS The results obtained by investigation of different sites from the South Atlantic make it possible to correlate geological and paleoceanographical events upon the whole area and to compare these events with those observed in the North Atlantic (Graciansky et al. 1982).

Hiatuses A major hiatus was recognized in the southern South Atlantic (Falkland Plateau) which represents at least a part of the Upper Aptian-Lowermost Albian (Sites 327 and 330). However, lack of information due to spot coring during this interval has to be taken in consideration. This hiatus might be linked with an important widening of the South Atlantic related to acceleration of spreading rate and reorganization of the plates between 111 and $107 \mathrm{Ma}$ (Rabinowitz \& La Breque 1979). This results in a more open circulation and the end of the anoxic conditions. This event can be correlated with E1 described from the Upper Aptian-Lowermost Albian of several sites in the North Atlantic (Muller et al. 1983-1984).

The second hiatus is present in all sites of the South Atlantic, representing almost always the entire Cenomanian (sites 511, 327, 356, 363, 364 and 361). It can be compared with event E2 in the North Atlantic. However, there, it is of longer extension, including also in most cases the Turonian. The absence of Cenomanian sediments due to the erosion is proved by the occurrence of reworked Cenomanian species (Rotalipora) in younger strata.

An unconformity in the Upper Turonian was recognized at Site 356 located on the Rio Grande Rise. It cannot be confirmed by observations from other sites because either the Turonian sediments are also eroded like the Cenomanian ones (Sites 511, 327, and 363), or there were no cores available, or zonal markers are missing. Since the Turonian sediments are usually a very condensed series (Herbin et al. 1985), it is possible that the complete interval is represented by a few centimetres or metres.

According to nannofossils, a smaller hiatus which seems 
to exist in several sites represents at least a part of the lower Campanian.

Anoxic Events One of the most striking phenomenon in the South Atlantic sedimentary sequences is the presence of two periods of anoxic conditions reflected by deposition of sediments rich in marine organic matter prevented from oxidation. That means an oxygen minimum in the water column or near the sediment surface. The oxygen minimum is confirmed by the absence of benthic foraminifers in the black shales. These two episodes are well separated by a period of oxic conditions ranging at least from Middle Albian to Middle Cenomanian times with the deposition of multicolored clay and mudstones.

As it can be recognized at Sites 511 and 330 (Falkland Plateau), anoxic conditions continued to exist since Late Jurassic time (Oxfordian-Callovian) up to the beginning of the Middle Albian. However, the progressive change towards an oxic environment began earlier in the southern South Atlantic (Aptian-Albian boundary) than in the Angola Basin (Middle Albian). This evolution is confirmed by the earlier appearance of benthic foraminifers in the South (Upper Aptian, Site 511) than further to the North (Middle Albian, Site 364). In the North Atlantic anoxic conditions existed throughout the Albian to Cenomanian times. This shows prograding widening and establishment of open circulation between the North and South Atlantic.

A second period of anoxic conditions existed around the Cenomanian-Turonian boundary and is correlated with the E2 event (Gracianski et al. 1982) or the "CenomanianTuronian boundary event" (Herbin et al. 1985) described from the North Atlantic and characterized by black shales with high contents of marine organic matter. It seems to be of global extension (Herbin et al. 1985). About their formation different hypothesis have been proposed. This time interval is characterized by an important transgression, most probably linked with an acceleration in spieading rate of the Mid-Atlantic Ridge (volcanic activities). Anoxic conditions were maintained in a rythmical manner during the Coniacian and Early Santonian times at Sites 364 and 530 located along the African margin North of the Walvis Ridge. Contemporaneous recurrent black shales are known at Sites 367 and 368 in the North Atlantic off NW Africa (Graciansky et al. 1982). Most probably it is related to particular local phenomena (upwelling? ).

Most of the black shales are barren of calcareous micro and nannofossils due to the high content of organic matter. However, radiolarians are present and often abundant, which might indicate a high primary productivity.

Paleoenvironments A connection between the South Atlantic and the Tethys has been established since MiddleLate Albian time (Moullade \& Guérin 1982) as indicated by the immigration of Ticinella primula and Planomalina buxtorfi (Site 356) into the area North of the Rio GrandeWalvis Ridge which acted like a barrier. It is only during
Coniacian time that the expansion of the Globotruncanids reached the SW of the South Atlantic (Site 511) (but Cenomanian-Turonian sediments are missing). However, whereas the northern basins contain tethyan planktonic assemblages throughout Upper Cretaceous time, the southwest faunas are austral in character up to Maastrichtian time. The general trend is the evolution to more diversified micro and nannoplankton assemblages since Albian time with the establishment of more open circulation pattern.

Another general trend is the continuous subsidence of the sites, reaching upper to middle bathyal environment by the end of the Albian and middle to lower bathyal conditions during the Late Cretaceous time. In all sites, a pronounced subsidence took place in the latest AlbianLower Cenomanian times as indicated by the occurrence of displaced shallow water benthic foraminifers (Globospirillina, Patellina, Nodosariids, large Marssonella, worn Miliolids) associated with a few neritic planktonic forms (Favusella, Gubkinella); the macrofauna, with solitary corals, Inoceramus, and particular sedimentary structures testify also the displacement of sediments from shallower dephts (shelf). By Middle Albian time, according to foraminifers, the water depth at Site 363 was shallower (outershelf) than those of Sites 327, 330, 511 (shelf break), and 364 (upper bathyal). Site 516, throughout its Late Cretaceous history remained slightly shallower than sites 357 and 356. Site 363 was also less deep than Site 364.

Dissolution is more important during the Upper Cretaceous time and is linked with subsidence of the sites to middle-lower bathyal conditions. But fluctuations of the CCD have also to be taken in consideration. In the Lower Cretaceous sequences, a strong dissolution occurred in the black shales because of the high content of organic matter. A general rise of the CCD in the South Atlantic can be observed in the lower part of the Coniacian-Santonian sedimentary sequences in which calcareous micro and nannofossils are either entirely dissolved or are only represent by dissolution resistant species. Dissolution also increased during Campanian time.

The South and North Atlantic show a similar evolution slightly decalated in time during the Early Cretaceous because of the progressively northward prograding opening of the Atlantic. The events became time equivalent with the fully established connection between the South and North Atlantic by Late Cretaceous time.

Acknowledgments Redescription of cores and appropriate sampling have been accomplished by P.C. de Graciansky, J.P. Herbin and T. Jacquin at the Lamont Doherty Geological Observatory. Thanks to the approval of the Chief Scientist of the Deep Sea Drilling Project and the help of the curatorial staff of the East Coast Repository. We wish also to thanks T. Jacquin for drafting the figure 2; C. Ponsot for reviewing the english text; and M.C. Geoffroy for typing the manuscript.

\section{REFERENCES}

BARKER, P.F.; DALZIEL, I.W.D., et al. - 1976 - Init. Repts. DSDP, 36, Washington (U.S. Govt. Printing Office).

BARKER, P.F.; CARLSON, R.L.; JOHNSON, D.A. - 1983 - Init. Repts. DSDP, 72, Washington (U.S. Govt. Printing office).
BOLLI, H.M.; RYAN, W.B.F., et al. - 1978 - Init. Repts. DSDP, 40, Washington (U.S. Govt. Printing Office).

CUSHMAN, J.A. - 1946 - Upper Cretaceous Foraminifera of the Gulf Coastal Region of the United States and adjacent areas. 
US Geological Survey Professional Paper, 206, 241 D.

DAILEY. D.H. - 1973 - Early Cretaceous foraminifera from the Budden Canyon Formation, northwestern Sacramento Valley, California. University of California Publications in Geological Sciences, 106, $111 \mathrm{p}$.

GRACIANSKY, P.C. de; BROSSÊ, E.; DEROO, G.; HERBIN, J.P.; MONTADERT, L.; MULLER, C.; SCHAAF, A.; SIGAL, J. 1982 - Les formations d'âge Crétace paléogéographie et milieux de dépôt. Rev. Inst. Franç. du Pétrole, 37(3):275-336.

GUEERIN. S. - 1981 - Utilisation des foraminifères planctoniques et benthiques dans l'étude des paiéoenvironnements océaniques au Crétacé moyen: application au matériel des forages D.S.D.P. de l'Atlantique Nord et Sud. Comparaison avec la Téthys Nice, 206p. (Tese de Doctorat de 3ème cycle, Nice).

HAIG, D.W. - 1979 - Global distribution patterns for mid-Cretaceous foraminiferids. J. Foram. Research., 9(1):29-40.

HANZLIKOVA, E. - 1972 - Carpathian Upper Cretaceous Foraminiferida of Moravia (Turonian-Maastrichtian). Ustredniho ustavu geologickeho, 39, $160 \mathrm{p}$.

HART, M.B. \& BAILEY, H.W. - 1979 - The distribution of planktonic loraminiferida in the Mid-Cretaceous of NW Europe. Init Union Geol. Sci., A 6: 527-542.

HART, M.B. \& BIGG, P.J. - 1981 - Anoxic events in the late Cretaceous chalk seas oi North-West Europe. In: NEALE, J.W. \& BRASIER, M.D. eds. Microfossils from recent and fossil shelf seas. The British Micropaleontological Society, Chapter 14 , p. 177-185.

HAY. W.W.; SIBUET, J.C. et al. - 1984 - Init. Repts. DSDP, 75, Washington (US. Govt. Printing Office).

HERBIN, J.P.; MULLER, C.; GRACIASKY, P.C. de; JACQUIN, T. MAGNIEZ-JANNIN, F.: UNTERNEHR, P. - 1987 Cretaceous anoxic events in the South Atlantic. Rev. Bras. Geoc. 17(2):92-99.

HOCH. W. - 1977 - Stratigraphie der Obeikreide in Nordwestdeutschland (Pompeckjsche Scholle). Teil 2: biostratigraphie in der Oberkreide und Taxonomie von Foraminiferen. Geol. $J b$., A 38: 11-123.

LONGORIA: J.F. - 1974 - Stratigraphic, morphologic and taxonomic studies of Aptian planktonic foraminifera. Revista Española de Micropaleontología, número extraordinário, 107p.

LUDWING, W.J.; KRASHENINNIKOV, V.A. et al. - 1983 - Init. Repts. DSDP 71, Washington (U.S. Govt. Priting Office).

MARKS, P. - 1984 - Integrated microfossil biostratigraphy Mid- Cretacecus (Albian to Santonian). Cretaceous Research. $5(1): 15-27$.

MOULLADE, M. \& GUÉRIN, S. - 1982 - Le problème des relations de l'Atlantique Sud et de l'Atlantique Central au Crétacé moyen: nouvelles données microfauniques d'après les forages D.S.D.P. Bul. Soc. Géol. France, (7) XXIV(3):511-517.

MULLER. C; SCHAAF A.; SIGAL, J. - 1983-1984 - Bio chronostratigraphie des formations d'âge crétacé dans les forages du DSDP dans l'océan Atlantique Nord. Part 1, Rev. Inst. Franç. du Pétrole, 38(6):683-708 (1983). Part 2, Rev. Inst. Franç. du Pétrole, 39(1):3-23 (1984).

ODIN, G.S. \& KENNEDY, W.J. - 1982 - Mise à jour de l'échelle des temps mésozoiques. C.R. Acad. Sc. Paris (II) 294:383-386.

PERCH-NIELSEN, K. - 1977 - Albian to Pleistocene calcareous nannofossils from the western South Atlantic, DSDP Leg 39. In: SUPKO, P.R.; PERCH-NIELSEN, K. et al. Init. Repts. DSDP, 39, Washington (U.S. Govt. Printing Office), p. 699-823.

PESSAGNO, Jr., E.A.; - i967 - Upper Cretaceous planktonic
Foraminifera from the Western Gulf Coastal Plain. Palaeontographica americana, c 37:245-445.

RABINOWITZ, P.D. \& LA BREQUE, J. - 1979 - The Mesozoic South Atlantic Ocean and evolution of its continental margins. J. Geophy. Res., 84(B11): 5973-6001.

ROBASZYNKI, F.; CARON, M. coord., et al. - 1979 - Atlas de foraminifères planctoniques du Crétacé moyen (Mer boréale et Téthys). Cahiers de Micropaléontologie, CNRS, 1979/1, 185 p., p1. 1-39; 1979/2, 181 p., p1. 40-80.

ROBASZYNSKI, F.; CARON, M.; GONZALES-DONOSO, J.M. WONDERS, A.A.H.; E.W.G.P.F. - 1983-1984 - Atlas of Late Cretaceous Globotruncanids. Rev. de Micropaléont., 26(3-4), 305 p., 54 p1.

SCHEIBNEROVA, V. - 1976 - Cretaceous Foraminifera of the Great Australian Basin. Memoirs of the Geological Survey of New South Wales, Paleontology, 17, 265 p.

SCHEIBNEROVÅ, V. - 1978 - Depth habitats of cretaceous foraminifera with special reference to Globotruncanids. Actes du VIO Coloque Africain de Micropaléontologie, Tunis, 1974. Annales des Mines et de la geólogie, Tunis, 28, p. 147-151.

SCHEIBNEROVÅ, V. - 1978 - Austral foraminifera and their importance for Cretaceous biostratigraphy and palaeogeography. Annales des Mines et de la géologie, Tunis, 28, p. 153-160.

SCHEIBNEROVÅ, V. - 1981 - Palaeogeographical implications of cretaceous benthic foraminifera recovered by the Deep Sea Drilling Project in the Western South Atlantic Ocean. Cretaceous Research, 2(1):1-18.

SCLATER, J.G.; HELLINGER, S.; TAPSCOTT, C. - 1977 - The paleobathymetry of the Atlantic Ocean from the Jurassic to the present. J. Geol., 85(5):509-552.

SIGAL, J. - 1977 - Essai de zonation du Crétacé méditerranéen à l'aide des foraminifères planctoniques. Géologie Méditerranéen$n e, \operatorname{IV}(2): 99-108$.

SLITER, W.V. \& BAKER, R.A. - 1972 - Cretaceous bathymetric distribution of benthic Foraminifers. J. Foram. Research, 2(4):167-183.

SLITER, W.V. - 1976 - Cretaceous foraminifera from the southwestern Atlantic Ocean, Leg 36, Deep Sea Drilling Project. In: BAKER, P.F., DALZIEL, I.W.D. et al. Init. Repts. DSDP, 36, Washington (U.S.Govt. Printing Office), p. 519-573.

SUPKO, P.R.; PERCH-NIELSEN, K. et al. - 1977 - Init. Repts. DSDP, 39, Washington (U.S. Govt. Printing Office).

THIERSTEIN, H.R. - 1973 - Lower Cretaceous calcareous nannoplankton biostratigraphy. Abh. Geol. Bundesanstalt, Wein, 29:3-52.

THIERSTEIN, H.R. - 1976 - Mesozoic calcareous nannoplankton biostratigraphy of marine sediments. Marine Micropaleontology, 1:325-362.

VAN HINTE, J.E. - 1976 - A cretaceous time scale. A.A.P.G. Bul., 60(4):498-516.

WEISS, W. - 1983 - Heterohelicidae (seriale planktonische Foraminiferen) der tethyalen Oberkreide (Santos bis Maastricht). Geologisches Jahrbuch, A ?2:3-93.

MANUSCRITO 400

Recebido em 30 de outubro de 1986 Revisão aceita em 30 de março de 1987

"Geologia é a ciência que investiga as sucessivas transformações ocorridas nos reinos orgânico e inorgânico da natureza, pergunta acerta dessas transformações e acerca da influência que elas exercem na modificação das estruturas internas e externas do nosso planeta". 